\title{
J-DEPACE
}

J-DEPACE, Volume 4, Nomor 1, Juni 2021, Hal 1-10

Tersedia online di :http://jurnal.lpmiunvic.ac.id/index.php/jpkm

\section{PELATIHAN PENGENALAN DASAR KOMPUTER DAN APLIKASI MICROSOFT OFFICE KEPADA ANAK-ANAK USIA SEKOLAH DI KELURAHAN KLAMALU KABUPATEN SORONG}

\author{
Frits G. J. Rupilele ${ }^{1}$, Aram Palilu ${ }^{2}$, Joseph Lopulalan ${ }^{\mathbf{3}}$, \\ La Ode Madina, ${ }^{4}$, Maya Pattiwael ${ }^{5}$, Fensca F. Lahallo ${ }^{6}$ \\ Universitas Victory Sorong \\ ${ }^{1}$ fritsrupilele@gmail.com ${ }_{2}{ }^{2}$ arampalilu@gmail.com, ${ }^{3}$ josephlopulalan@gmail.com, \\ ${ }^{4}$ laodemadinanoken@gmail.com, ${ }^{5}$ mayapattiwael@gmail.com, ${ }^{6}$ ekalahallo120@gmail.com
}

\begin{abstract}
ABSTRAK
Tujuan yang ingin dicapai dari dilaksanakan pelatihan dasar komputer ini adalah: Mengenalkan kepada peserta pelatihan mengenai pentingnya Penguasaan Teknologi Informasi dan Komputer saat ini serta mengajarkan bagaimana menggunakan Aplikasi Microsoft Word yang dapat digunakan untuk belajar mengetik dan lainnya. Metode yang digunakan pada kegiatan ini adalah Pendidikan kepada Masyarakat (PkM) berupa ceramah dan pelatihan tentang pengenalan dasar komputer dan aplikasi Microsoft office khusus Microsoft word. Hasil dari kegiatan PkM ini adalah memberikan implikasi pada penambahan wawasan peserta tentang komputer dan aplikasinya. Mengingat kegiatan Pendidikan yang semasa pandemik covid-19 dilaksanakan secara daring/online menjadikan banyak keterbatasan anak-anak usia sekolah dalam mengembangkan keterampilan terkhususnya praktek penggunaan komputer. Hal ini terlihat dari hasil evaluasi yang dilakukan sebelum dan setelah diadakannya kegiatan pelatihan. Dimana terdapat peningkatan pemahaman dan pengetahuan sebelum dan setelah dilaksanakannya kegiatan.
\end{abstract}

Kata kunci: Pengenalan Dasar Komputer, Aplikasi Microsoft Office 


\section{ABSTRACT}

The objectives to be achieved from this basic computer training are: Introducing training participants to the importance of Mastering Information Technology and Computers today and teaching how to use Microsoft Word applications that can be used to learn typing and others. The method used in this activity is Public Education in the form of lectures and training on the introduction of basic computers and Microsoft office applications specifically for Microsoft word. The result of the Mini Pk activity is to provide implications for increasing participants' insight about computers and their applications. Considering that educational activities during the covid19 pandemic were carried out online, there were many limitations for school-age children in developing skills, especially the practice of using computers. This can be seen from the results of the evaluation conducted before and after the training activities. Where there is an increase in understanding and knowledge before and after the activity.

Keywords: Basic Introduction to Computers, Microsoft Office Applications

\section{PENDAHULUAN}

Pada era globalisasi seperti ini perkembangan teknolongi informasi sangatlah cepat berkembang diseluruh dunia. Dengan berkembangnya teknologi informasi yang seperti sekarang ini hampir setiap orang dituntut untuk mengikuti perkembangan teknologi. Dengan berkembangnya teknologi informasi di dunia terutama di Indonesia begitu juga di daerah perkotaan dan pedesaan ini sangan potensial untuk membantu mengkedepankan pendidikan (TI) demi mengikuti perkembangan teknologi yang berkembang dengan pesat. Untuk keadaan masyarakat pedesaan saat ini belum mengikuti perkembangan teknologi yang maju dan berkembang karena kurangnya sarana teknologi seperti komputer. Hal ini di sebabkan kurangnya kesadaran masyarakat akan kegunaan komputer dalam kehidupan sehari-hari. Sedangkan di kota tidaklah sulit, jika ingin mengikuti perkembangan teknologi karena di kota banyak terdapat sarana-sarana teknologi seperti komputer, sedangkan di pedesaan memang cukup sulit untuk mengakses informasi karena minimnya sarana komputer.

Penguasaan teknologi informasi dan komunikasi menjadi penting karena setiap pihak yang terlibat di dalamnya dituntut mampu berpartisipasi secara aktif dan terus meningkatkan kemampuan berkompetisi. Teknologi Informasi dan Komunikasi sudah menjadi kebutuhan primer bagi banyak kalangan. Dengan menggunakan Teknologi Informasi dan Komunikasi, suatu proses dan kegiatan dapat dilakukan dengan lebih cepat, mudah dan efisien (Rupilele, 
2019). Oleh karena itu penguasaan terhadap perangkat teknologi komunikasi perlu diajarkan pada semua tingkatan.

Suatu realitas, pemerintah telah menjadikan Teknologi Informasi dan Komunikasi menjadi mata pelajaran (IT as a subject) wajib pada tingkat sekolah dasar dan sekolah menengah. Bekal kemampuan menggunakan dan memanfaatkan perangkat teknologi informasi dan komunikasi merupakan salah satu faktor kunci untuk mengejar ketertinggalan SDM Indonesia dari bangsabangsa lain. Program-program pendidikan dan latihan secara formal maupun non formal yang memberikan bekal ketrampilan dan kemampuan dalam menggunakan dan memanfaatkan perangkat teknologi informasi dan komunikasi menjadi prioritas kebutuhan. Jalur pendidikan formal berpotensi dan bernilai strategis untuk menyelenggarakan pendidikan dan latihan di bidang TIK yang idealnya dimulai sejak dini. Hal ini mengisyaratkan pentingnya bagi anakanak sejak dini disediakan pengalaman dalam memanfaatkan sarana teknologi informasi dan komunikasi khususnya komputer yang bermanfaat sebagai bekal kemampuan dasar dan potensi untuk belajar sepanjang hayat dan memecahkan masalah yang akan dihadapi dalam kehidupannya kelak (Pujiriyanto, 2009).

Kondisi dunia dan khususnya Negara Indonesia saat ini sementara digonjangkan dengan adanya penyebaran wabah virus Covid-19 yang mengharuskan masyarakat untuk tetap stay di rumah dan hanya keluar rumah jika ada masalah yang sangat penting dan tidak dapat dihindarkan. Hal ini pun berdampak pada dunia pendidikan. Proses pembelajaran tidak terjadi secara langsung. Proses pembelajaran berlangsung secara daring atau menggunakan aplikasi virtual conference. Bagi anak usia sekolah jenjang pendidikan SMA atau setidaknya telah mempelajari tentang pemanfatan teknologi informasi, akan mempermudah mereka untuk menyesuaikan dengan perubahan sistem pelaksanaan pendidikan. Kendala yang sangat dirasakan adalah bagi anak usia sekolah pada jenjang SD dan SMP (Madina et al., 2019). Mereka perlu dibekali dengan pemahaman dan pengetahuan penggunaan teknologi informasi. Sistem pembelajaran daring seperti ini juga berdampak pada pelaksaan praktek mata pelajaran aplikasi komputer. Permasalahan ini dapat diatas oleh anak- anak yang memiliki pemahaman serta fasilitas komputer tetapi kesulitan besar bagi anak-anak yang memiliki ekonomi keluarga yang kurang yang memiliki keterbatasan dalam kepemilikan fasilitas sedangkan tuntutan pemanfatan teknologi mengharuskan mereka untuk menyesuaikan dengan perubahan yang 
terjadi. Hal ini juga akan berdampak pada kurangnya keterampilan mereka dalam pemanfaatan aplikasi komputer.

\section{MASALAH}

Khusus pada generasi penerus yang ada di Kelurahan Klamalu Kabupaten Sorong, terutama anak - anak usia sekolah, perlu dibekali dan pengenalan komputer sebagai bekal mereka dalam menjawab tantangan perkembangan dunia di masa - masa yang akan datang. Maksud dari kegiatan ini adalah memberikan Pelatihan Pengenalan Dasar Komputer dan Aplikasi Microsoft Office khusus Microsoft Word kepada anak-anak usia sekolah di Kelurahan Klamalu Kabupaten Sorong. Tujuan yang ingin dicapai dari dilaksanakan pelatihan dasar komputer ini adalah: Mengenalkan kepada peserta pelatihan mengenai pentingnya Penguasaan Teknologi Informasi dan Komputer saat ini serta mengajarkan bagaimana menggunakan Aplikasi Microsoft Word yang dapat digunakan untuk belajar mengetik dan lainnya.

\section{METODE PELAKSANAAN}

Metode yang digunakan pada kegiatan ini adalah Pendidikan Masyarakat berupa ceramah dan pelatihan tentang pengenalan dasar komputer dan aplikasi Microsoft office word yang bertujuan untuk mengenalkan kepada peserta pelatihan tentang penguasaan teknologi informasi dan komputer serta meningkatkan pemahaman peserta yang terdiri dari anak-anak usia sekolah yang ada di Kelurahan Klamalu Kabupaten Sorong dalam penggunaan Microsoft office word. Dalam pelatihan ini, para peserta juga diminta untuk mempraktekkan materi yang sudah disampaikan sebelumnya. Sebelum pelaksanaan kegiatan, hal yang perlu dilakukan adalah observasi atau pengamatan terlebih dahulu untuk pengumpulan data atau fakta yang berkaitan dengan kebutuhan materi dari peserta pelatihan. Observasi ini dilakukan untuk mengetahui kesulitan- kesulitan yang dialami oleh peserta dalam mengoperasikan komputer.

Adapun tahapan-tahapan dalam pelaksanaan kegiatan ini adalah:

1) Ceramah digunakan untuk menyampaikan pengetahuan secara umum tentang pemanfaatan aplikasi keterampilan dasar komputer

2) Tanya jawab digunakan untuk melengkapi hal-hal yang belum dipahami oleh peserta pelatihan.

3) Pelatihan menggunakan Microsoft office Word, dengan melibatkan seluruh peserta 
pelatihan.

4) Evaluasi dilakukan dengan cara pengamatan langsung melalui penilaian kinerja peserta untuk mengetahui pemahaman peserta tentang komputer dan aplikasi Microsoft office word setelah pelatihan dilakukan

\section{HASIL DAN PEMBAHASAN}

\section{A. Pelaksanaan Kegiatan}

Adapun pelaksanaan kegiatan pengabdian kepada masyarakat dilaksanakan pada :

Hari/ Tanggal : Sabtu, 26 Juni 2021

Waktu $\quad$ : Pkl 08.00-13.00 WIT

Tempat : Kelurahan Klamalu Kabupaten Sorong

Agenda $\quad$ : Pelatihan Pengenalan Dasar Komputer dan Aplikasi Microsoft Office

khusus Microsoft Word kepada anak-anak usia sekolah di Kelurahan Klamalu Kabupaten Sorong.
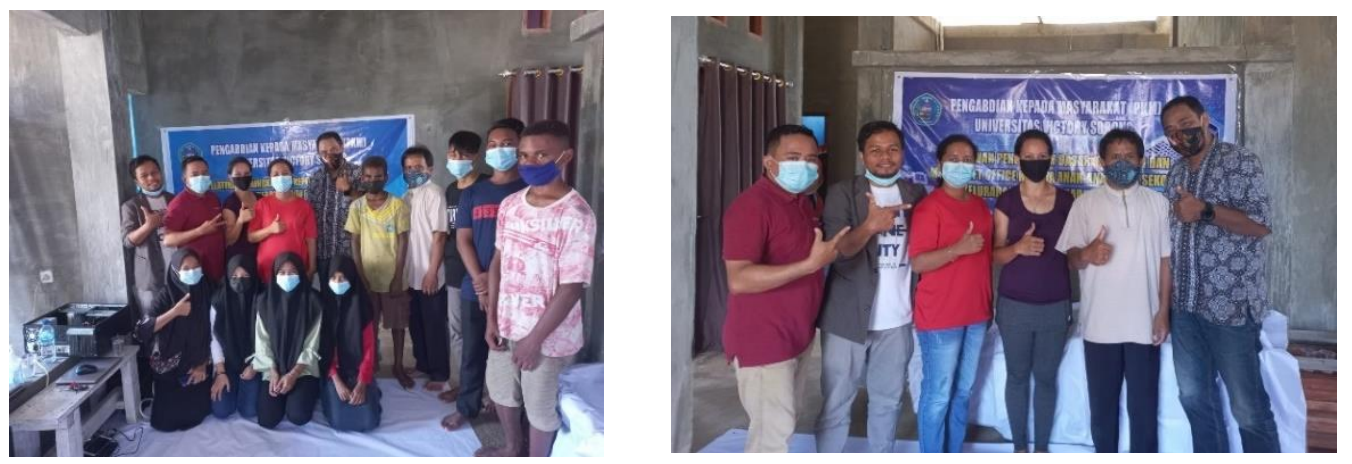

Gambar 4.1 Pelaksanaan Kegiatan PkM

\section{B. Hasil Kegiatan}

Indonesia merupakan salah satu negara yang terdampak masalah pandemi covid-19, demikian juga terjadi di Provinsi Papua Barat terutama pada daerah Kabupaten Sorong. Sampai saat ini, kebijakan pemerintah daerah dalam penagangan masalah pandemi dengan memberlakukan aktivitas masyarakat memasuki fase new normal artinya masyarakat dihimbau untuk hidup berdampingan dengan Virus covid-19 artinya tetap dianjurkan pelaksanaan kegiatan di luar rumah dengan tetap mentaati protokol Kesehatan. Hal tersebut dilakukan untuk 
memulihkan Kesehatan negara, keadaan ekonomi maupun sosial. Akan tetapi dunia Pendidikan dari awal pandemik sampai saat ini masih menerapkan kegiatan Pendidikan secara daring/online. Hal ini mengakibatkan seluruh proses pembelajaran dilaksanakan secara tidak langsung melalui berbagai program atau aplikasi meeting conference. Hal ini memberikan manfaat positif maupun negatif. Anak-anak usia sekolah didorong untuk menguasai dan mendayagunakan teknologi secara efektif dan efisien.

Sekalipun tetap stay dirumah tetapi mereka tetap dapat memperoleh pengetahuan melalui pembelajaran daring. Akan tetapi, kendala yang dapat dialami oleh anak-anak yang tidak memiliki akses terhadap fasilitas pembelajaran secara online/kurangnya pemahaman tentang penggunaan aplikasi komputer akan sangat sulit melalui proses pembelajaran saat ini jika tidak dibantu oleh orang tua/wali. Anak-anak akan lebih banyak memperoleh pembelajaran yang lebih banyak berperan pada perkembangan kognitif tetapi dari segi pemenuhan keterampilan terkhusus pada pembelajaran tentang penguasan komputer menjadi kendala yang cukup berarti. Hal ini menjadi suatu dorongan bagi tim PkM dalam melaksanakan kegiatan pengabdian dengan tema "Pelatihan Pengenalan Dasar Komputer Dan Aplikasi Microsoft Office Kepada Anak-Anak Usia Sekolah Di Kelurahan Klamalu Kabupaten Sorong.” Maksud dari kegiatan ini adalah memberikan Pelatihan Pengenalan Dasar Komputer dan Aplikasi Microsoft Office khusus Microsoft Word kepada anak-anak usia sekolah di Kelurahan Klamalu Kabupaten Sorong. Tujuan yang ingin dicapai dari dilaksanakan pelatihan dasar komputer ini adalah: Mengenalkan kepada peserta pelatihan mengenai pentingnya Penguasaan Teknologi Informasi dan Komputer saat ini serta mengajarkan bagaimana menggunakan Aplikasi Microsoft Word yang dapat digunakan untuk belajar mengetik dan lainnya.

Adapun tahapan-tahapan dalam pelaksanaan kegiatan ini adalah:

\section{Persiapan Kegiatan}

Tim PkM melakukan persiapan sebelum kegiatan dilaksanakan. Kegiatan persiapan dimulai dengan penyiapan tempat pelatihan, persiapan fasilitas/media pelatihan seperti infokus, laptop/notebook, kelengkapan administrasi kegiatan (absensi/daftar hadir). 

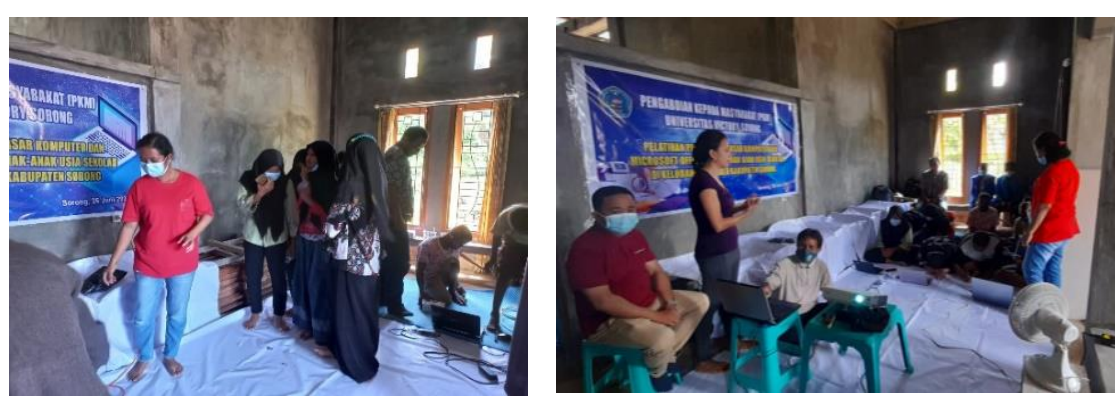

Gambar 4.2 Tim PkM melakukan persiapan kegiatan

\section{Perkenalan}

Kegiatan ini dilakukan sebelum kegiatan inti dilaksanakan yaitu penyampaian materi tentang pengenalan komputer dan pelatihan penggunaan Microsoft word. Agar kegiatan ini dapat berlangsung dengan baik, maka perlu adanya pengenalan antara tim PkM dan peserta kegiatan dengan tujuan untuk saling mengenal dan dapat mempermudah interaksi dalam kegiatan dimaksud.
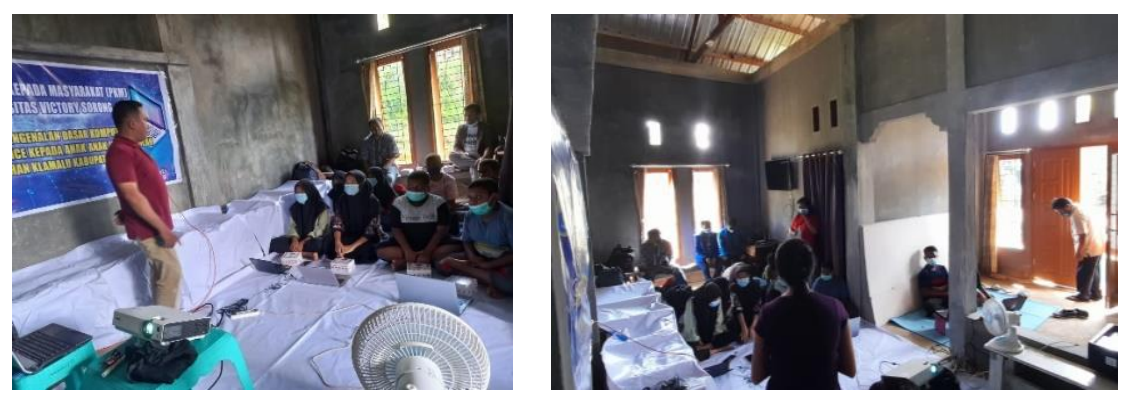

Gambar 4.3 Proses Perkenalan antara Tim PkM dan Peserta Pelatihan

\section{Penyampaian materi tentang pengenalan komputer}

Dalam penyampaian materi, disampaikan berbagai konsep tentang komputer yang dimulai dengan :

a. pengertian komputer

b. Rumusan Komputer yang terdiri dari Perangkat masukan (input device), perangkat proses (central processing unit), dan perangkat keluaran (output device)

c. Manfaat komputer yang meliputi komputer sebagai sarana dalam mempermudah pekerjaan, sarana komunikasi, sarana informasi, sarana usaha, sarana alat Kesehatan, sarana hiburan, dan lain sebagainya. 
d. Perbedaan Komputer dan Laptop dari segi harga/biaya, Kinerja, Perakitan, Daya listrik, dan Kepraktisan.

e. Komponen Utama Sistem Komputer yang terdiri dari hardware, software, brainware and data.

1) Dalam pembahasan tentang komponen hardware, peserta dibekali dengan pengetahuan maupun contoh konkrit berdasarkan fungsi perangkat keras dibagi menjadi tiga yaitu Perangkat masukan (input device), perangkat proses (central processing unit), perangkat keluaran (output device), maupun external device.

2) Dalam pembahasan tentang software, peserta dibekali dengan pengetahuan tentang operating sistem (OS), Program Aplikasi, Programming language

3) Dalam pembahasan tentang brainware (user), peserta dibekali dengan pemahaman tentang pelaku yang membuat program atau sekedar menggunakan program.
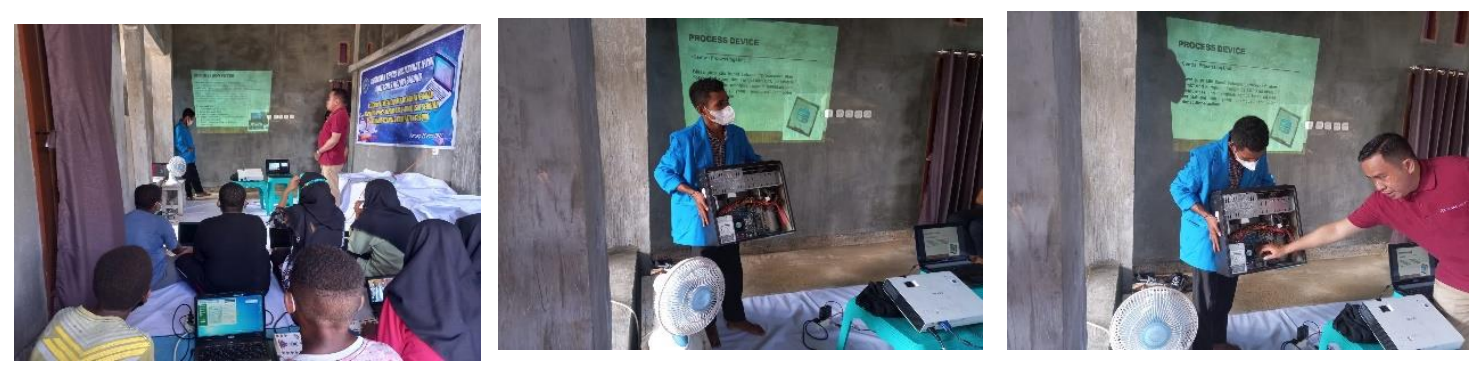

Gambar 4.4 Penjelasan tentang komponen computer

4. Kegiatan Tanya Jawab

Kegiatan tanya jawab dilakukan dengan tujuan untuk melengkapi hal-hal yang belum dipahami oleh peserta pelatihan serta mengukur sampai sejauh mana tingkat kepahaman peserta pelatihan dalam menguasai aplikasi computer maupun kegiatan pelatihan penggunaan Microsoft office terkhusus Microsoft word.

5. Pelatihan menggunakan Microsoft office Word, dengan melibatkan seluruh peserta pelatihan.

Dalam kegiatan pelatihan ini, peserta pelatihan dibekali dengan pengetahuan tentang Microsoft office terkhusus Microsoft word. Peserta dilatih untuk membuat dokumen baru, menyimpan dan menutup lembar kerja, membuka dokumen yang telah dibuat, mengatur ukuran kertas dan margin, mengatur format teks, mengatur perataan paragraph, mengatur 
Frits G. J. Rupilele, dkk Pelatihan Pengenalan Dasar Komputer dan Aplikasi Microsoft Office ... spasi antar baris, pemberian nomor halaman, membuat header and footer, membuat bullet and numbering, mengganti kata.
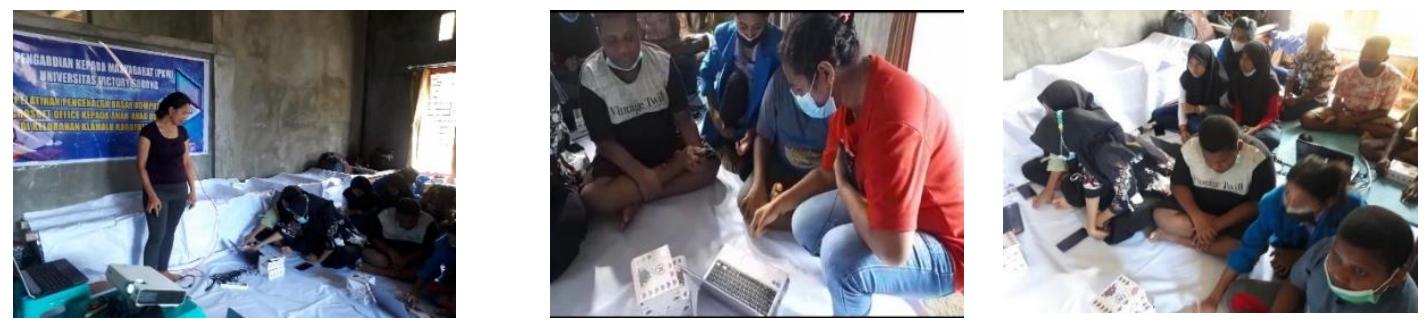

Gambar 4.5 Pelatihan Penggunaan Microsoft Word

6. Kegiatan Evaluasi

Evaluasi dilakukan dengan cara pengamatan langsung melalui penilaian kinerja peserta untuk mengetahui pemahaman peserta tentang komputer dan aplikasi Microsoft office word setelah pelatihan dilakukan.
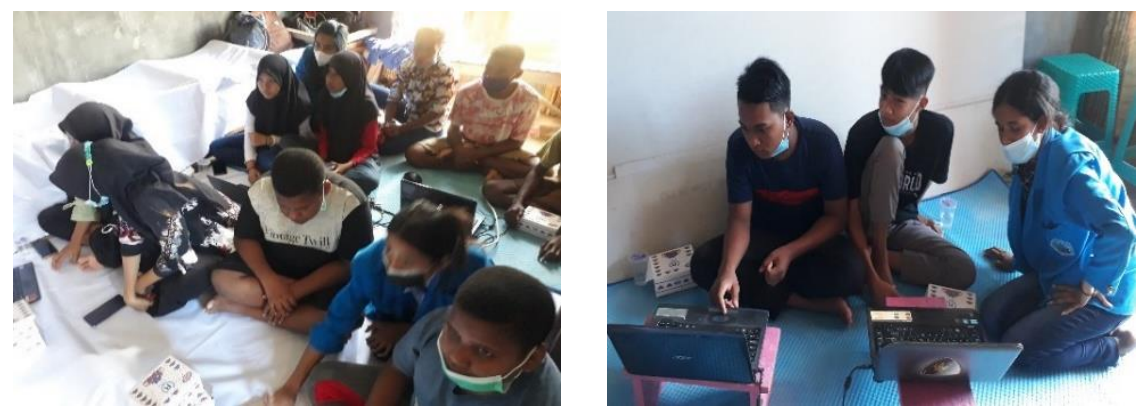

Gambar 4.6 Kegiatan Evaluasi

\section{KESIMPULAN}

Maksud dari kegiatan PkM yang melibatkan anak-anak usia sekolah pada jenjang SD, SMP, dan SMA di Kelurahan Klamalu Kabupaten Sorong adalah memberikan Pelatihan Pengenalan Dasar Komputer dan Aplikasi Microsoft Office khusus Microsoft Word kepada anak-anak usia sekolah di Kelurahan Klamalu Kabupaten Sorong. Tujuan yang ingin dicapai dari dilaksanakan pelatihan dasar komputer ini adalah: Mengenalkan kepada peserta pelatihan mengenai pentingnya Penguasaan Teknologi Informasi dan Komputer saat ini serta mengajarkan bagaimana menggunakan Aplikasi Microsoft Word yang dapat digunakan untuk belajar mengetik dan lainnya. Pelaksanaan kegiatan ini disambut baik oleh peserta dan kegiatan ini pun dapat memberikan implikasi pada penambahan wawasan peserta tentang komputer dan 
aplikasinya. Mengingat kegiatan Pendidikan yang semasa pandemik covid-19 dilaksanakan secara daring/online menjadikan banyak keterbatasan anak-anak usia sekolah dalam mengembangkan keterampilan terkhususnya praktek penggunaan komputer. Hal ini terlihat dari hasil evaluasi yang dilakukan sebelum dan setelah diadakannya kegiatan pelatihan. Dimana terdapat peningkatan pemahaman dan pengetahuan sebelum dan setelah dilaksanakannya kegiatan.

\section{DAFTAR PUSTAKA}

Abdulhak, H. I. \& Sanjaya, W. (2005). Media Pendidikan: Suatu Pengantar. Bandung: Pusat Pelayanan dan Pengembangan Media Pendidikan UPI Bandung

Asmani, Jamal Ma'mur. (2011). Tips Pemanfaatan Teknologi Informasi dan Komunikasi dalam Dunia Pendidikan. Yogyakarta: DIVA Press

Rupilele, F. G. J. (2019). Pemanfaatan Sistem Monitoring Kegiatan Tri Dharma PT oleh Lembaga Penjaminan Mutu Internal Universitas Victory Sorong. Journal of Dedication to Papua Community. https://doi.org/10.34124/269164

Munir. (2009). Pembelajaran Jarak Jauh Berbasis Teknologi Informasi dan Komunikasi. Bandung: Alfabeta

Madina, L. O., Pattiwael, M., Lahallo, F., Rupilele, F., \& Palilu, A. (2019). Penggunaan Bahasa Indonesia Yang Baik Dan Benar Dalam Berkomunikasi. J-DEPACE (Journal of Dedication to Papua Community), 2(2), 157-170.

Pujiriyanto, (2009). Peranan Komputer Sebagai Media Pembelajaran Bagi Anak, Dinamika Pendidikan, Vol. 16, No. 1, FIP, Universitas Negeri Gorontalo

Prasojo, Lantip Diat dan Riyanto. (2011). Teknologi Informasi Pendidikan. Yogyakarta: Gava Media

Warsita, Bambang. (2008). Teknologi Pembelajaran: Landasan \&Aplikasinya. Jakarta: Rineka 